Annals of Plant and Soil Research 23(2): 170-174 (2021)

https://doi.org/10.47815/apsr.2021.10051

\title{
Effect of tillage and crop establishment practices on performance of rice (Oryza sativa) under rice-wheat cropping system
}

\author{
PRATIBHA KUMARI ${ }^{*}$, P.K. SHARMA, REENA KUMARI ${ }^{1}$ AND U.P. SINGH ${ }^{2}$ \\ Department of Soil Science and Agricultural Chemistry, Institute of Agricultural Sciences, Banaras Hindu \\ University, Varanasi-221005, Uttar Pradesh, India
}

Received: February, 2021; Revised accepted: March, 2021

\begin{abstract}
A field experiment was conducted at Agricultural Research Farm, Institute of Agricultural Sciences, Banaras Hindu University, Varanasi, Uttar Pradesh during Kharif season of 2018. The experiment consisted of six combinations of different tillage methods and crop establishment practices with four-time replicated under randomized block design. Zero tillage [direct seeded rice - wheat (Full CA; anchored residue of rice and wheat + mungbean residue retention)]showed significantly higher plant height, number of tillers $\mathrm{m}^{-2}$ and chlorophyll content as compared to the other treatments, while the lowest values of these parameters were observed under conventional tillage (rice-wheat without residue). There was a steady rise in plant height and number of tillers with age of plant under all the treatments. The yield and its attributes were significantly higher under zero tillage [direct seeded rice - wheat (full CA; anchored residue of rice and wheat + mungbean residue retention)] followed by treatments zero tillage [direct seeded rice - wheat (full CA; anchored residue of rice and wheat)]. While, the poor yield was reported in conventional tillage (rice-wheat without residue). Zero tillage [direct seeded rice - wheat (full CA; anchored residue of rice and wheat + mungbean residue retention)] increased nutrient use efficiency in term of partial factor productivity of applied NPK in rice crop.
\end{abstract}

Keywords: Rice, Tillage, Crop Establishment Practices, Yield, Correlation coefficient and Partial factor productivity (PFP)

\section{INTRODUCTION}

The rice-wheat cropping system is one of the largest agricultural production systems of the world, occupying 10.0 million hectares of cultivated land in the Indo-Gangetic Plains (IGP) in South Asia (Sharma et al.2020). The sustainability of this system is at risk as rice yield is stagnating or even declining and total factor productivity is also declining. Possible reasons are: a deteriorating natural resource base, unmanaged use of inputs, changing climate, enhancing water and labor scarcity, increasing cost of cultivation, energy crisis, rising fuel prices and emerging socio-economic changes. Rice is the staple food of more than half of the world's population. Puddling of rice field created a plow layer that reduces hydraulic conductivity to support water ponding, which minimized the water percolation losses and enhanced the water and nutrient use efficiency of rice. Although puddling has positive effects on rice, it is water-, capital-, and energy-intensive. Puddling also deteriorates soil physical properties by destroying soil aggregates, forming hard-pans at shallow depth, and lowering permeability in the subsurface layer (Kalita et al. 2020). Tillage, one of the most important practices in agriculture, performed primarily to mix the soil with organic residues and fertilizer, to loose the upper layer of soil, to check weeds and to create a suitable seedbed for germination and plant growth. Among the crop production factors, tillage contributes up to $20 \%$ and affects the sustainable use of soil resources through its influence on soil properties (Sharma et al. 2018). Recently, resource-conserving tillage (RCTs) and crop establishment (CE) methods have received increased attention to address soil health issues, reduce turnaround time between rice and wheat, and reduce cost of land preparation and CE methods. RCTs such as zero tillage and unpuddled transplanting have been shown to be beneficial in terms of improving soil health, water use, crop productivity and farmer's income. Conservation agriculture (CA) - based technologies improve production and income, and address the emerging problems. CA is known for its role in improving soil fertility in terms of its physical,

Corresponding author email- pratibha.sona@ gmail.co, ${ }^{1}$ N. M. College of Agriculture, Navsari Agricultural University, Navsari, Gujarat

${ }^{2}$ Department of Agronomy, Banaras Hindu University, Varanasi 
chemical, and biological properties and in turn improves overall soil health, water-use efficiency, crop productivity, system productivity and farmers' income. Beyond this, the practice has multiple benefits in increasing the overall system performance. Singh et al. (2012) concluded that CA based double no till increased the input use efficiency, productivity and profitability of rice crop in rice-wheat system at the farm front in Indo-Gangetic Plains of Eastern India. The objective of this study was to identify the most appropriate tillage and residual management practices for improving the growth and yield of the rice crop in the most dominant cropping system in Eastern Uttar Pradesh.

\section{MATERIALS AND METHODS}

A field experiment was conducted at Agricultural Research Farm, Institute of Agricultural Sciences, Banaras Hindu University, Varanasi, Uttar Pradesh during Kharif 2018. The climate is semi-arid to sub-humid with hot dry summer and cold winters. The soil is sandy loam. The soil was non-saline (EC $0.34 \mathrm{dSm}^{-1}$ ) of neutral reaction $(\mathrm{pH} \mathrm{7.3)}$ and contained 3.4 $\mathrm{gkg}^{-1}$ organic carbon, $192 \mathrm{~kg} \mathrm{ha}^{-1}$ available $\mathrm{N}$, $21.4 \mathrm{~kg} \mathrm{ha}^{-1}$ available $\mathrm{P}$ and $224.0 \mathrm{~kg} \mathrm{ha}^{-1}$ available $\mathrm{K}$. The experiment comprised six treatments which were replicated four-time under a randomized block design. The details of the treatment were $\mathrm{T}_{1}$-Conventional tillage (ricewheat without residue), $\mathrm{T}_{2}$-Conventional tillage [rice-wheat without residue (mungbean residue incorporation)], $\mathrm{T}_{3}$-Conventional tillage direct seeded rice- zero tillage wheat (Partial CA; anchored residue of rice), $\mathrm{T}_{4}$-Conventional tillage direct seeded rice- zero tillage wheat (Partial CA; anchored residue of rice + mungbean residue incorporation), $\mathrm{T}_{5}$-Zero tillage [direct seeded rice - wheat (Full CA; anchored residue of rice and wheat)] and $T_{6}$-Zero tillage [direct seeded rice wheat (Full CA; anchored residue of rice and wheat + mungbean residue retention)]. The rice crop (variety-DRR-44) was sown in July of 2018. A uniform dose of $150 \mathrm{~kg} \mathrm{~N}, 60 \mathrm{~kg} \mathrm{P}_{2} \mathrm{O}_{5}, 60 \mathrm{~kg}$ $\mathrm{K}_{2} \mathrm{O}$ and $5 \mathrm{~kg} \mathrm{Zn} \mathrm{ha}^{-1}$ was applied in all the treatments through urea, DAP, muriate of potash and zinc sulphate respectively. Half of total nitrogen and full dose of $\mathrm{P}_{2} \mathrm{O}_{5}, \mathrm{~K}_{2} \mathrm{O}$ and $\mathrm{Zn}$ were applied as basal (sowing) and remaining half dose of nitrogen was top dressed in two equal splits, at active tillering and panicle initiation stage. Plant height, the number of tillers $m-2$ was recorded at different intervals. Chlorophyll content was estimated using Soil Plant Analysis Development (SPAD) chlorophyll meter at different growth stages. The grains panicle ${ }^{-1}$ and test weight at harvest was recorded. Nutrient use efficiency in terms of Partial factor productivity (PFP) of applied nutrients was calculated in the unit of crop yield harvested per unit of nutrient applied. Yield of the crop was recorded at harvest. The data were statistically examined using the analysis of variance (ANOVA) technique (Gomez and Gomez 1984). Critical difference (CD) was computed to assess significance of treatment means at $5 \%$ level of probability.

\section{RESULTS \& DISCUSSION}

The growth parameters viz. plant height and tillers $\mathrm{m}^{-2}$ of rice were significantly affected by the different tillage and crop establishment practices (Table 1). The plant height was recorded significantly higher $(35.5 \mathrm{~cm})$ under zero tillage [direct seeded rice - wheat (Full CA; anchored residue of rice and wheat + mungbean residue retention)] as compared to the rest of the treatment at 30 days after sowing (DAS) while, at 60,90 , and at harvest it was statistically at par with zero tillage [direct seeded rice - wheat (Full $\mathrm{CA}$; anchored residue of rice and wheat)] and higher than the rest of the treatments. The tillers $\mathrm{m}^{-2}$ was statistically higher under zero tillage [direct seeded rice - wheat (Full CA; anchored residue of rice and wheat + mungbean residue retention)] at 30,60, and 90 DAS as compared to the rest of the treatments. At harvest, maximum tillers $\mathrm{m}^{-2}$ (423.1) was recorded under zero tillage [direct seeded rice - wheat (Full CA; anchored residue of rice and wheat + mungbean residue retention)] which was statistically at par with zero tillage [direct seeded rice - wheat (Full $\mathrm{CA}$; anchored residue of rice and wheat)] and significantly higher $22.7 \%$ than conventional tillage (rice-wheat without residue). Maximum chlorophyll content was obtained 33.0 and 40.1 SPAD value under zero tillage [direct seeded rice - wheat (Full CA; anchored residue of rice and wheat + mungbean residue retention)] at 30 and 60 DAS (Fig. 1). The lowest chlorophyll content was obtained 30.8 and 35.2 SPAD value under conventional tillage (rice-wheat without 


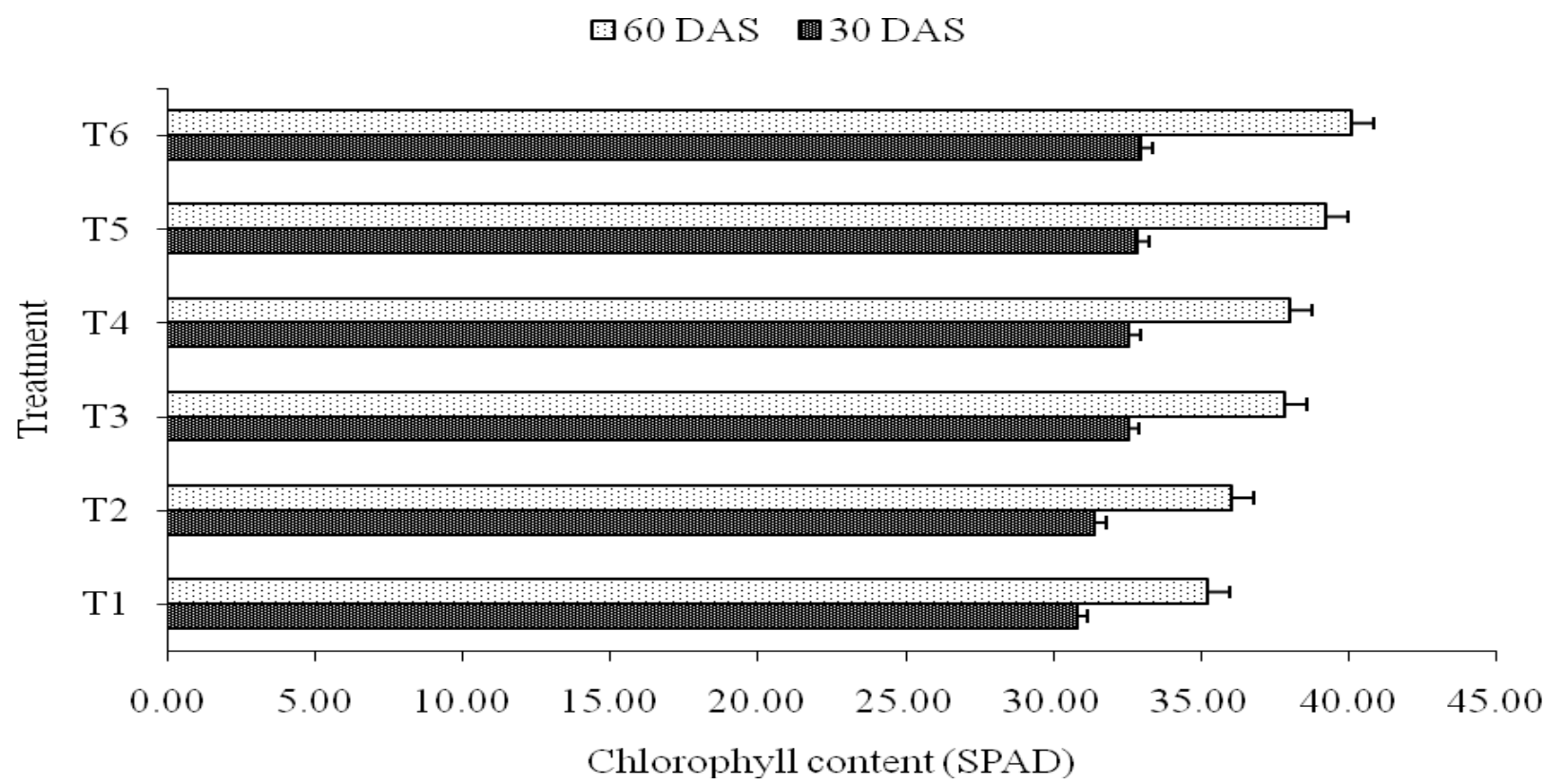

Fig. 1: Effect of tillage and crop establishment practices on Chlorophyll content (SPAD) of rice ( $p=0.05$ level of significance), bar denoted standard error

residue) at 30 and 60 DAS. High residue retention reported to delay the phenological development in rice by retaining soil moisture and supporting vegetative growth for longer time
(Devkota 2013). The zero-tilled and residue incorporated conservation treatment probably conserved moisture and enhanced vegetative growth (Seeraj et al. 2018).

Table 1:Effect of tillage and crop establishment practices on plant height and no. of tillers of rice

\begin{tabular}{|c|c|cc|c|cccc|}
\hline \multirow{2}{*}{ Treatment } & \multicolumn{5}{|c|}{ Plant height $(\mathrm{cm})$} & \multicolumn{4}{c|}{ Number of tillers $\mathrm{m}^{-2}$} \\
\cline { 2 - 9 } & 30 DAS & 60 DAS & 90 DAS & At harvest & 30 DAS & 60 DAS & 90 DAS & At harvest \\
\hline $\mathrm{T}_{1}$ & 23.2 & 69.3 & 77.8 & 94.2 & 168.1 & 340.3 & 354.6 & 344.7 \\
$\mathrm{~T}_{2}$ & 25.1 & 71.2 & 79.3 & 95.1 & 169.8 & 344.4 & 359.2 & 347.2 \\
$\mathrm{~T}_{3}$ & 27.9 & 74.2 & 83.2 & 99.8 & 174.9 & 364.8 & 387.8 & 379.7 \\
$\mathrm{~T}_{4}$ & 30.5 & 77.9 & 86.0 & 101.9 & 176.2 & 376.8 & 394.9 & 385.9 \\
$\mathrm{~T}_{5}$ & 33.6 & 82.5 & 91.2 & 105.3 & 182.7 & 397.7 & 421.2 & 416.6 \\
$\mathrm{~T}_{6}$ & 35.5 & 85.3 & 92.8 & 109.7 & 187.5 & 408.1 & 430.7 & 423.0 \\
$\mathrm{SEm} \pm$ & 0.41 & 1.03 & 1.41 & 1.63 & 1.49 & 3.52 & 2.93 & 2.42 \\
$\mathrm{CD}(\mathrm{P}=0.05)$ & 1.20 & 3.02 & 4.11 & 4.75 & 4.36 & 10.29 & 8.59 & 7.08 \\
\hline
\end{tabular}

The grains per panicle were recorded significantly higher under zero tillage [direct seeded rice - wheat (Full CA; anchored residue of rice and wheat+ mungbean residue retention)] (159.4 panicles $^{-1}$ ) as compared with other treatments except zero tillage [direct seeded rice - wheat (Full CA; anchored residue of rice and wheat)]. Test weight and harvest index were non-significantly affected by tillage and crop establishment practices. However, highest test weight and harvest index were recorded $24.2 \mathrm{~g}$ and $40.3 \%$ under zero tillage [direct seeded rice - wheat (Full CA; anchored residue of rice \& wheat + mungbean residue retention)] respectively (Table 2$)$. The grain $\left(4.23 \mathrm{t} \mathrm{ha}^{-1}\right)$ and straw $\left(6.26 \mathrm{t} \mathrm{ha}^{-1}\right)$ yield were recorded significantly higher under zero tillage [direct seeded rice - wheat (Full CA; anchored residue of rice and wheat+ mungbean residue retention)] as compared to conventional tillage (rice-wheat without residue) treatment. The lowest grain and straw yields were obtained (3.54 and $5.34 \mathrm{t} \mathrm{ha}^{-1}$ respectively), under conventional tillage (ricewheat without residue). The highest biological yield (10.49 $\left.\mathrm{t} \mathrm{ha}^{-1}\right)$ was recorded under zero tillage [direct seeded rice-wheat (Full CA; 
anchored residue of rice and wheat + mungbean residue retention)], followed by zero tillage [direct seeded rice - wheat (Full CA; anchored residue of rice and wheat)] (10.34 $\left.\mathrm{t} \mathrm{ha}^{-1}\right)$. Some favourable factors like improvement in labile carbon fraction, $\mathrm{C}$ stock, and better soil physical condition, were created by conservation agriculture practice which is responsible for the significant increase in grain yield. Jat et al. (2014) reported that higher rice grain yield was obtained in conventional tillage based rice systems than in conservation agriculture-based systems.

Table 2: Effect of tillage and crop establishment practices on yield and it's attributes of rice

\begin{tabular}{|c|c|c|c|c|c|c|}
\hline Treatment & $\begin{array}{c}\text { Grains } \\
\text { Panicle }^{-1}\end{array}$ & $\begin{array}{c}\text { Test weight } \\
\text { (g) }\end{array}$ & $\begin{array}{c}\text { Harvest } \\
\text { Index(\%) }\end{array}$ & $\begin{array}{l}\text { Grain yield } \\
\left(\text { tha }^{-1}\right)\end{array}$ & $\begin{array}{c}\text { Straw yield } \\
\left(\text { tha }^{-1}\right)\end{array}$ & \begin{tabular}{|c|} 
Biological yield \\
$\left(\right.$ tha $\left.^{-1}\right)$
\end{tabular} \\
\hline $\mathrm{T}_{1}$ & 132.2 & 20.6 & 39.8 & 3.54 & 5.34 & 8.88 \\
\hline $\mathrm{T}_{2}$ & 135.7 & 21.8 & 39.9 & 3.61 & 5.42 & 9.03 \\
\hline $\mathrm{T}_{3}$ & 146.1 & 22.4 & 40.0 & 3.97 & 5.94 & 9.91 \\
\hline $\mathrm{T}_{4}$ & 148.4 & 22.9 & 40.1 & 4.08 & 6.10 & 10.18 \\
\hline$T_{5}$ & 156.7 & 23.3 & 40.2 & 4.16 & 6.18 & 10.34 \\
\hline $\mathrm{T}_{6}$ & 159.4 & 24.2 & 40.3 & 4.23 & 6.26 & 10.49 \\
\hline SEm \pm & 1.07 & 1.08 & 0.38 & 0.14 & 0.23 & 0.37 \\
\hline$C D(P=0.05)$ & 3.12 & NS & NS & 0.42 & 0.68 & 1.08 \\
\hline
\end{tabular}

The results showed that the grain and straw yield had a highly significant positive correlation with grains panicle ${ }^{-1}$ (Table 3 ). The lowest correlation of grain and straw yield was recorded (0.95 and 0.94) with plant height, respectively. The range of PFP of nitrogen value as overall, observed between 23.6 and $28.2 \mathrm{~kg}$ $\mathrm{kg}^{-1}$ while PFP of phosphorus and potassium ranged from 59.0 to $70.5 \mathrm{~kg} \mathrm{~kg}^{-1}$ (Fig. 2). The maximum PFP of nitrogen was recorded under zero tillage [direct seeded rice-wheat (full CA; the anchored residue of rice and wheat + mungbean residue retention)] followed by zero tillage [direct seeded rice-wheat (full CA; anchored residue of rice \& wheat)]. Conventional tillage (rice-wheat without residue) gave 16.3\% lower PFP of $\mathrm{P}$ and $\mathrm{K}$ than zero tillage [direct seeded rice-wheat (full CA; anchored residue of rice and wheat + mung bean residue retention)].

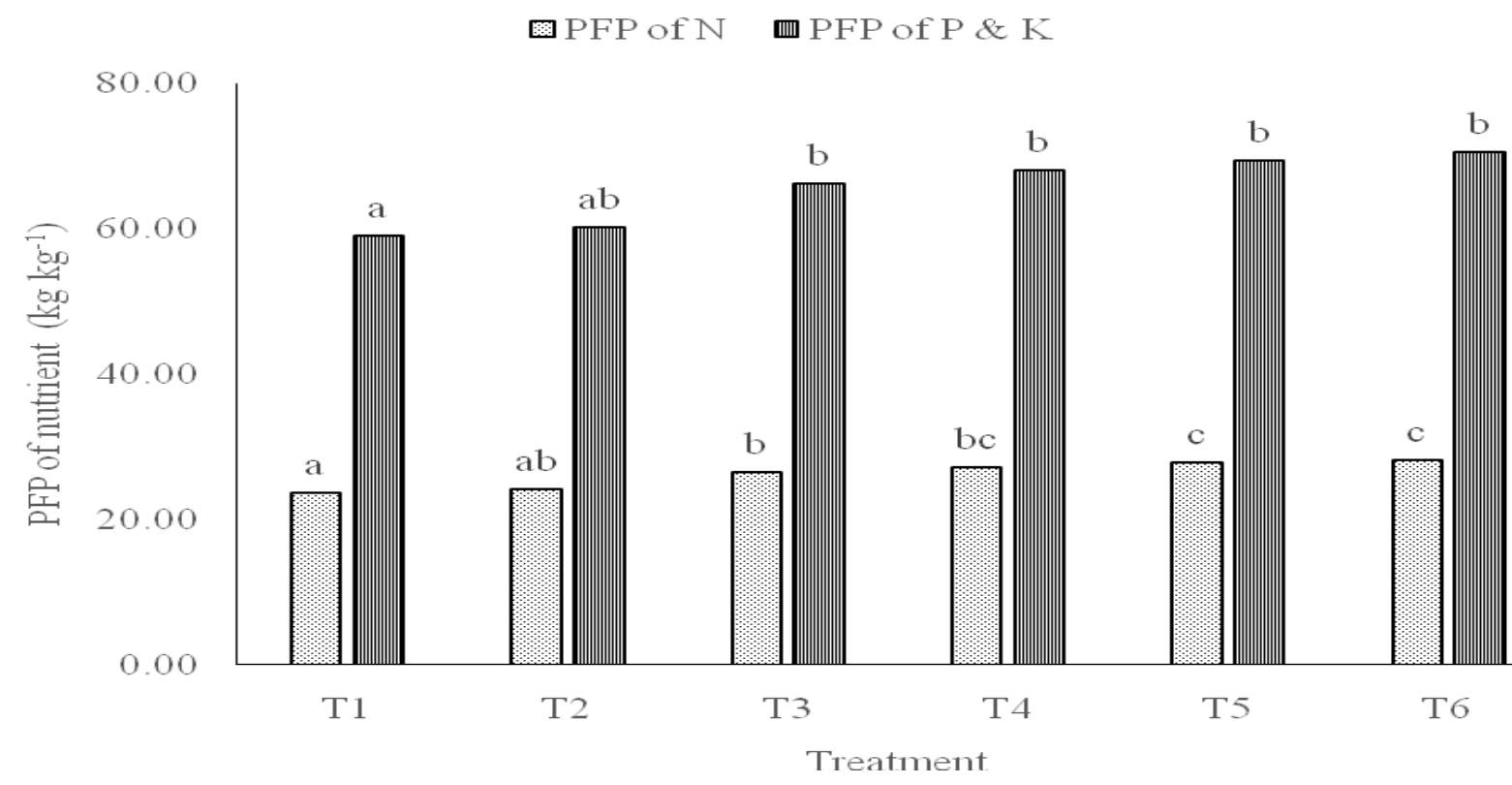

Fig. 2: PFP of nutrient of rice as affected by tillage and crop establishment practices ( $p=0.05$ level of significance) 
Table 3: Correlation between different parameters of rice crop under Tillage and Crop Establishment Practices ( $p=0.05$ level of significance)

\begin{tabular}{l|c|c|c|c|c|}
\hline \multicolumn{1}{|c|}{ Parameters } & Number of tillers & Plant height & Grains per panicle & Grain yield & Straw yield \\
\hline Number of tillers & 1.00 & & & & \\
Plant height & 0.98 & 1.00 & & & \\
Grains per panicle & 0.99 & 0.98 & 1.00 & & \\
Grain yield & 0.96 & 0.95 & 0.98 & 1.00 & \\
Straw yield & 0.95 & 0.94 & 0.97 & 0.99 & 1.00 \\
\hline
\end{tabular}

It may be concluded that the conservation agriculture practice of rice proved superior to conventional tillage in terms of growth and yield. Direct-seeded rice followed by wheat under zero tillage with residue retention (mung bean) had superior growth and finally higher yield as compared to the other conservation tillage and convention tillage methods. The conservation agriculture with

\section{REFERENCES}

Devkota, K.P., Manschadi, A., Lamers, J.P.A., Devkota, M. and Vlek, P.L.G. (2013) Mineral nitrogen dynamics in irrigated ricewheat system under different irrigation and establishment methods and residue levels in arid drylands of Central Asia. European Journal of Agronomy 47: 65-76.

Gomez, K.A. and Gomez, A.A. (1984) Statistical Procedures for Agricultural Research. $2^{\text {nd }}$ edn. International Rice Research Institute. John Willy and Sons, New York, pp 120-134.

Jat, R.K., Sapkota, T.B., Singh, R.G., Jat, M.L., Kumar, M. and Gupta, R.K. (2014) Seven years of conservation agriculture in a ricewheat rotation of Eastern Gangetic Plains of South Asia: yield trends and economic profitability. Field Crops Research 164: 199-210.

Kalita, J., Ahmed, P. and Baruah, N. (2020) Puddling and its effect on soil physical properties and growth of rice and post rice crops: A review. Journal of Pharmacognosy and Phytochemistry 9(4): 503-510 direct seeding and legume residue retention also performed well and can be adopted in rice growers in Indian sub-continent. However, in the future some alternative diversified cropping system should be evaluated in Indo-Gangetic Plain of South Asia, which will be profitable to farmer as well as sustainable for environment, soil health and food security.

Seeraj, P., Das D.K., Das T.K., Mukherjee J., Krishnan P., Sehgal V.K. and Kumar S.N. (2018) Growth, Yield and Radiation Interception of Rice under Conservation Agriculture Practices. Journal of Agricultural Physics 18(2): 240-245.

Sharma, B., Kumari, P., Kumari, R. and Tripathi, S.K. (2018) Soil Tillage and Alteration of Soil Properties by Tillage Operation. In: Current Research in Soil Science (ISBN 978-93-88112-80-2), Published by AkiNik Publications, New Delhi. pp 105-114.

Sharma, P., Singh, M.K., Verma, K. and Prasad S.K. (2020) Changes in the weed seed bank in long-term establishment methods trials under rice-wheat cropping system. Agronomy 10(2): 292.

Singh, U.P., Singh, Y., Sutaliya, J.M., Ravikumar H.S., Jat M.L. and Gupta R.K. (2012) Performance of double no-till in rice-wheat system of Eastern Indo-Gangetic plains, Inproceeding of $3^{\text {rd }}$ International Agronomy Congress: Agriculture Diversification, Climate Change Management and Livelihoods. New Delhi, India, pp. 838-839. 